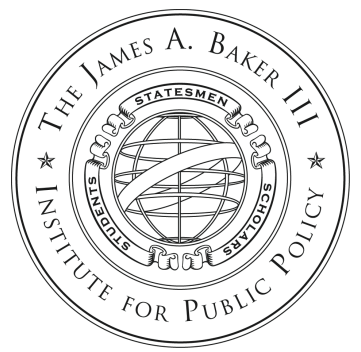

James A. Baker III Institute for Public Policy

RICE UNIVERSITY

\title{
CAPITAl MobILITY AND CAPITAL TAX COMPETITION
}

\author{
BY \\ George R. Zodrow, Ph.D. \\ Allyn R. and Gladys M. Cline Chair of ECONOMics, AND \\ Rice SCholar, James A. BAKer III INSTitute for Public Policy, \\ RICE UNIVERSITY \\ international Research Fellow, Centre for Business Taxation, \\ OXFORD UNIVERSITY
}

JULY 3, 2009 


\section{Capital Mobility and Capital Tax Competition}

THESE PAPERS WERE WRITTEN BY A RESEARCHER (OR RESEARCHERS) WHO PARTICIPATED IN A BAKER INSTITUTE RESEARCH PROJECT. WHEREVER FEASIBLE, THESE PAPERS ARE REVIEWED BY OUTSIDE EXPERTS bEFORE THEY ARE RELEASED. HOWEVER, THE RESEARCH AND VIEWS EXPRESSED IN THESE PAPERS ARE THOSE OF THE INDIVIDUAL RESEARCHER(S), AND DO NOT NECESSARILY REPRESENT THE VIEWS OF THE JAMES A. BAKER III INSTITUTE FOR PUbLIC POLICY.

(C) 2009 By the James A. BAker III Institute for Public Policy of Rice University

A REVISED VERSION OF THIS PAPER IS FORTHCOMING IN THE NATIONAL TAX JOURNAL.

THIS MATERIAL MAY BE QUOTED OR REPRODUCED WITHOUT PRIOR PERMISSION, PROVIDED APPROPRIATE CREDIT IS GIVEN TO THE AUTHOR AND THE JAMES A. BAKER III INSTITUTE FOR PUBLIC POLICY. 


\section{Capital Mobility and Capital Tax Competition}

I have benefited greatly from the comments of Charles McLure, and from suggestions from the participants at a conference on “Mobility and Tax Policy: Do Yesterday's Taxes Fit Tomorrow's Economy?" held at the Center for Business and Economic Research, University of Tennessee, Knoxville, TN, on October 2-3, 2008. I would like to thank Leslie Countryman for research assistance. 


\section{Introduction}

The implications for tax policy of increasing mobility of factors of production and goods in the modern global economy is certainly an important topic, underlying many debates on tax reform at all levels. Critical to these debates are the extent to which the mobility of capital has increased and, if it has, the extent to which it has resulted in interjurisdictional tax competition designed to attract such mobile capital and the effects of such competition. This paper examines several strands of the literature that shed light on these questions.

To keep the analysis manageable, it is circumscribed in several ways. The paper focuses on international capital mobility and tax competition, although it briefly considers some subnational issues as well. In addition, the analysis focuses on the mobility of foreign direct investment; however, there is also some limited discussion of portfolio investment, especially in the context of the literature on savings-investment correlations. Finally, the paper generally focuses on the effects of tax competition in terms of the reallocation of physical capital across jurisdictions. However, an underlying theme is that taxes can also affect the tax base without affecting the

physical location of capital investment, by creating incentives for multinational enterprises to shift income across jurisdictions - although the ability to engage in such income shifting may temper the investment disincentive effects of relatively high host country tax rates and thus limit tax competition.

The paper is organized as suggested by the discussion above- the following section discusses various attempts to measure capital mobility while Section III considers various studies that attempt to discern the extent of tax competition. Section IV concludes.

\section{Capital Mobility}

This section examines three different ways that economists have attempted to discern the extent of capital mobility: (1) estimating the effects of taxation on foreign direct investment, (2) estimating the incidence of taxes on capital, especially corporate income taxes, to see if the results are consistent with a high degree of capital mobility, and (3) examining saving and 


\section{Capital Mobility and Capital Tax Competition}

investment correlations and identifying their implications for capital mobility. Before proceeding, it may be useful to note that there is general agreement about three important points related to the extent of international capital mobility. First, the volume of capital flows, including both portfolio capital and foreign direct investment, has grown dramatically, suggesting that capital has become more mobile over time (Hines, 2007). Second, barriers to international capital flows have declined significantly over time and have been accompanied by widespread deregulation of financial markets and dramatic advances in information and communication technology - factors that have operated to increase international capital mobility (Feldstein and Bacchetta, 1991; Coakley, Kulasi and Smith, 1998). Finally, the empirical evidence is generally consistent with perfect capital mobility in the sense that interest rates on deposits of the same maturity and risk characteristics and expressed in the same national currency tend to be equalized (Frankel, 1993; Obstfeld, 1995). However, Obstfeld (1995) also notes that little has been learned about international capital mobility from cross-country comparisons of rates of return on assets in different currencies, as such returns incorporate expected changes in exchange rates as well as an exchange-rate risk premium, and that the empirical evidence in general does not support uncovered interest rate parity under these circumstances (Frankel, 1993; Smallwood and Norrbin, 2008). The implications of these empirical results are discussed in more detail below.

\section{A. Tax Sensitivity of Foreign Direct Investment}

A natural way to measure the mobility of capital is to estimate the sensitivity of capital flows to changes in after-tax rates of return, including those caused by changes in tax variables. Unfortunately, obtaining accurate estimates is fraught with difficulty, including both measurement problems and a wide range of troublesome econometric issues.

For example, as in all econometric studies, it is difficult to disentangle the relationships of interest - those between investment decisions and tax policy-from the many other factors that affect these investment decisions. These factors include proximity to markets, the costs of various primary and intermediate inputs, the skill levels available in local labor markets, the existence of economies of agglomeration, the local competitive, legal and regulatory environment, and the degree of political stability including the credibility of commitments to enforce property rights. 
Furthermore, it can be similarly difficult to disentangle the effects of host and home country taxes for investments by multinationals based in countries, like the U.S. and the U.K., that operate residence-based tax systems with foreign tax credits. Under very special circumstances, host country taxes are irrelevant to the FDI decisions of multinationals in countries with foreign tax credits, since any host country tax reductions will be offset by higher domestic taxes. However, the importance of this "treasury transfer" argument is severely limited by numerous factors, including the facts that (1) host country taxes are current while home country tax credits are deferred until dividends are repatriated by a foreign subsidiary to its parent, (2) many multinationals are in an excess foreign tax credit position and thus receive little if any benefits from additional credits, (3) some countries that allow foreign tax credits also provide for "tax sparing" which implies that host country tax incentives for FDI are not offset by additional domestic tax liability, and (4) some U.S. multinationals use tax avoidance techniques, described in Zodrow (2008), that eliminate home country tax liability. Indeed, most empirical evidence suggests that these factors are sufficiently important that host country taxes are the primary determinants of FDI. ${ }^{1}$

Measurement problems also plague econometric analyses of tax effects on multinational investment decisions. A major issue is the determination of the appropriate tax rate variable to use in analyzing these effects. Given the complexity of modern corporate tax systems simply using the statutory tax rate is likely to yield misleading results. The simplest alternative approach is to use an average tax rate, calculated as the ratio of taxes paid to some measure of before-tax profits. An important advantage of this approach is that it captures the effects of explicit tax preferences and firm-specific "negotiated" tax reductions, as well as the effects of tax planning activities. In addition, as stressed by Devereux and Hubbard (2003), average tax rates will be the critical variable in determining tax incentives for investments by multinationals that are characterized by discrete strategic choices, imperfectly competitive markets and significant economic rents. However, average effective tax rates typically also capture the effects of

\footnotetext{
${ }^{1}$ See Zodrow (2003) for further discussion of these issues. Note that to the extent the "treasury transfer" effect described above is operative, host countries face a difficult tax design problem, as they must weigh the "treasury transfer" revenue benefits of higher tax rates against the costs of discouraging investment from multinationals with excess foreign tax credits or from countries that do not allow foreign tax credits. This in turn implies that the optimal tax policy for any given country depends critically on the sources of its FDI, and that this dependence will change over time with changes in these sources (e.g., with the emergence of China as an important capital exporter).
} 


\section{Capital Mobility and Capital Tax Competition}

previous tax structures on old investments, which are largely irrelevant to current investment decisions (although, as will be discussed below, some researchers have calculated prospective average effective tax rates under various assumptions about the extent of above-normal returns).

The most popular alternative to the average tax rate is the marginal effective tax rate, which looks at the effects of the existing tax system on a prospective investment, taking into account not only statutory rates but also the detailed provisions of the tax code that determine the tax treatment of investment (depreciation deductions, inventory accounting, investment tax credits or allowances, inflation adjustment, etc.), the characteristics of the investment (asset mix, method of finance, assumed inflation rate, etc.) as well as the interactions between the host and home country tax systems (King and Fullerton, 1984). The major drawback of the marginal effective tax rate approach is that it is in fact marginal - that is, it reflects only the taxation of marginal investments, such as incremental investments in competitive markets that typically do not yield economic rents. However, as suggested above, multinational investments are typically characterized by firm-specific or location-specific economic rents. For this reason, some analysts argue that average effective tax rates should be used to analyze tax effects on foreign direct investment - in particular, average effective tax rates can also be used to analyze the effects of the existing tax code on prospective investments, but under the assumption that the future investment will earn positive economic rents (Devereux and Griffith, 1998; Devereux and Hubbard, 2003). ${ }^{2}$

The empirical research on taxes and investment, especially the most recent work, has attempted to deal with these issues. There is a general consensus that this empirical evidence demonstrates that FDI is in fact sensitive to tax factors, and suggests that this sensitivity may be increasing over time. For example, Gordon and Hines $(2002,49)$ conclude that the "econometric work of the last fifteen years provides ample evidence of the sensitivity of the level and location of FDI to its tax treatment." A similar conclusion is reached by de Mooij and Ederveen (2003, 2005), who perform "meta analyses" of the literature, in which they correlate the results of a wide range

\footnotetext{
${ }^{2}$ Similar issues arise with respect to the measurement of FDI. The standard definition of FDI includes not only real investment in property, plant and equipment (PPE) but also capital acquired through mergers and acquisitions. However, the PPE concept (which also includes investment financed with local debt that is excluded from FDI) is closer in spirit to the capital stock notions used in the theoretical analyses described above. Accordingly, although FDI is used in most studies, PPE has been utilized as the measure of foreign investment in several recent studies.
} 
of empirical studies of the effects of taxes on FDI to the characteristics of the underlying studies. Several econometric approaches have been utilized in this literature. The early studies were primarily time series analyses that estimated the effects of variations in host country tax rates on aggregate FDI. ${ }^{3}$ Gordon and Hines (2002) conclude that these studies suggest an elasticity of FDI with respect to after-tax returns of approximately 1.0, which is roughly equivalent to an investment elasticity with respect to effective tax rates of about -0.6 , for both FDI by U.S. multinationals and for FDI in the U.S. by multinationals based in other countries. Cross-section studies of the effects of variations of host country tax rates across countries on multinational investments in property, plant and equipment (PPE) suggest somewhat greater sensitivity of investment to tax rates, with elasticities around -1.0 (Hines and Rice, 1994; Grubert and Mutti, 2000). Perhaps more importantly, the most recent and most careful studies-especially Altshuler, Grubert and Newlon (2001) and Grubert and Mutti (2001), as well as de Mooij and Ederveen (2003) - tend to obtain the largest estimates. For example, Altshuler, Grubert and Newlon estimate that the elasticity of investment with respect to after-tax host country rates of return for U.S. multinationals increased from 1.5 in 1984 to 2.8 in 1992. Grubert and Mutti (2001) estimate an investment elasticity of roughly 3 for countries with relatively open trade regimes. Finally, for the sample of studies they analyze, de Mooij and Ederveen calculate a median estimate of the investment elasticity of 3.3; they also note that the more recent studies tend to obtain the largest elasticities. ${ }^{4}$

These studies are limited to data from the early 1990s. An interesting complication is that increasing tax avoidance activity on the part of U.S. multinationals suggests that foreign direct investment may become less sensitive to taxes, since the burden of high host country rates can be more easily avoided. Nevertheless, more recent research suggests that, at least through 2000, the tax sensitivity of FDI is not declining and may even still be increasing. For example, Altshuler and Grubert (2006) examine data for 1992, 1998 and 2000, and find that their estimated investment tax elasticities are increasing over the period (with some estimates in the range of -4), although this result is quite tentative as the differences in the elasticities over time are not

\footnotetext{
${ }^{3}$ For example, see Hartman (1984), Boskin and Gale (1987); Young (1988) and Slemrod (1990).

${ }^{4}$ In closely related research, Clausing (2007) estimates the responsiveness of the corporate tax base to corporate rates to calculate the revenue maximizing tax rate for a sample of 29 OECD countries. She estimates an overall revenue maximizing rate of 33 percent for the sample as a whole, with lower values for smaller, more open economies.
} 


\section{Capital Mobility and Capital Tax Competition}

statistically significant. ${ }^{5}$ However, Overesch (2009) provides some contrasting evidence. He examines investment in relatively high-tax Germany by multinationals based in lower tax countries, and finds that a one percentage point increase in the tax differentials between the two countries increases investment in Germany by nearly one percent - a result that he attributes to greater potential for income shifting to ameliorate the effects of the high German statutory tax rate.

To sum up, the empirical literature as a whole suggests that international capital is quite mobile and in particular is significantly affected by tax factors. However, there is some preliminary evidence which suggests that the tax sensitivity of FDI may be reduced by possibilities to shift income to lower tax countries and thus ameliorate the effects of relatively high statutory tax rates.

\section{B. The Incidence of Corporate Taxes}

Another interesting approach infers the mobility of capital from results on the incidence of taxes on capital income, most often the corporate income tax. The theoretical models that have appeared in the literature have strong implications for the incidence of a source-based tax on capital if such capital is mobile. Indeed, in the simplest models in which the taxing jurisdiction is a small open economy, capital bears none of the burden of the tax which, with the assumption of perfectly mobile capital, is borne by local factors, land and relatively immobile labor, and consumers of nontradable goods. By comparison, if the taxing jurisdiction is large but capital is mobile among all jurisdictions, the share of the burden of the tax borne by capital is roughly equal to its share of the world capital stock. Indeed, in more complicated general equilibrium models with perfectly mobile capital, a tax on capital income may be shifted more than 100 percent to labor. For example, Harberger (1995, 2008) constructs a four-sector general equilibrium model in which labor must bear all the burden of the corporate income tax since capital is perfectly mobile and the price of the output of the corporate sector is fixed on world markets. But since labor is mobile across production sectors, the price of labor in other sectors declines as well. As a result, labor bears more than 100 percent of the burden of the tax-130 percent in the central case analyzed by Harberger (2008). These models suggest that a test of

\footnotetext{
${ }^{5}$ Similar results are reported by de Mooij and Ederveen (2005) in an update of their 2003 study.
} 


\section{Capital Mobility and Capital Tax Competition}

capital mobility is whether taxes on capital income are in fact shifted to labor, especially in small open economies.

This reasoning has been questioned by Gravelle and Smetters (2006), who argue that, even if capital is perfectly mobile internationally, capital in the US will bear more of the burden of the corporate income tax than the US share of world output if domestic goods and imports are not perfect substitutes. In a model similar to that constructed by Harberger, they show that the capital share of the tax burden increases dramatically as the substitutability between domestic goods and imports falls. For example, if the elasticity of substitution in consumption between traded corporate domestic goods and imports is reduced from infinity to 3.0 (a value that Gravelle and Smetters argue is consistent with the empirical literature), the share of the tax burden on domestic capital increases from roughly 30 percent to 62 percent.

However, the Gravelle and Smetters result has been challenged on two grounds. First, McDaniel and Balistreri (2002) note that many trade economists are skeptical of the relatively low estimates of import substitution elasticities found in the literature. Similarly, Harberger (2008) argues that relatively low elasticities of substitution imply an implausibly large degree of market power for domestic producers. Moreover, several recent studies have obtained significantly higher estimates of the import substitution elasticity. For example, Erkel-Rousse and Mirza (2002) estimate an overall import substitution elasticity of 3.8, with many industries characterized by elasticities between 6.5-7.0 and some as high as 13.0, and Hertel, et al. (2004) obtain an estimated import substitution elasticity for 40 different products of 7.0, with estimates that exceed 10 in some cases.

Second, Randolph (2006) argues that a plausible extension of the model constructed by Gravelle and Smetters dramatically alters its results. Specifically, he extends the Gravelle-Smetters model to allow a domestic corporate sector that produces two types of traded goods - some that are perfect substitutes for imports and others that are imperfectly substitutable. In this case, if the capital intensities in the two corporate tradable goods sectors are identical, the incidence of the corporate income tax is independent of the degree of import substitutability in the second sector 


\section{Capital Mobility and Capital Tax Competition}

and, if capital is perfectly mobile, capital bears slightly less than 30 percent of the corporate tax burden in the U.S., as predicted in the simplest tax incidence models noted above.

Taken together, these results suggest that empirical estimates of the incidence of a tax on capital income would provide some useful information on the extent of capital mobility. Estimating the incidence of corporate income taxes is notoriously difficult, especially in country cross-section analyses that face the daunting task of controlling for a multitude of factors other than the corporate income tax that might affect wages and the process of wage determination within each country. Nevertheless, three recent studies have attempted to do so and thus indirectly shed light on the question of the mobility of capital.

Each of these studies examines various samples of OECD countries and estimates that differences in corporate income taxes across countries are to a large extent reflected in differences in wages. ${ }^{6}$ Arulampalam, Devereux and Maffini (2008) analyze micro data on wages from France, Italy, Spain and the UK over the period 1993-2003 in the context of a wage bargaining model that determines how firm owners and labor divide economic rents, including how the corporate income tax affects this division of rents. (They thus do not consider explicitly the tax-induced capital emigration stressed above.) Their central estimates suggest that 62 percent of the corporate income tax is borne by labor in the short run, and labor fully bears the burden of the tax in the long run.

Hassett and Mathur (2006) examine a large sample of 72 countries using data from 1981-2002, looking at the relationship between five-year averages of hourly wages in manufacturing and corporate income taxes, measured using either statutory tax rates, effective marginal tax rates, or average effective tax rates. They estimate extremely large elasticities of the labor tax burden with respect to the various measures of the corporate tax rate that range between $0.5-1.0 .^{7}$ Indeed, Gravelle and Hungerford (2007) argue that the results are highly implausible, as a wage elasticity of 1.0 would imply that a one percent increase in corporate revenues would be accompanied by a

\footnotetext{
${ }^{6}$ For an excellent analysis of these studies, including more details on the methods used, see Gentry (2007).

${ }^{7}$ In addition, Hassett and Mathur find that higher tax rates in neighboring countries are associated with higher wages in the taxing country, and that labor tends to bear a larger fraction of the corporate income tax in smaller countries, results that are both consistent with the tax competition arguments described above.
} 


\section{Capital Mobility and Capital Tax Competition}

fall in wages that would be roughly 26 times as large. They replicate the Hassett-Mathur analysis under different assumptions and obtain much smaller effects of the corporate tax on wages.

Finally, Felix (2007) examines a sample of 19 OECD countries over the period 1979-2002. She uses the statutory tax rate as a measure of the corporate tax burden and analyzes labor compensation for workers at three skill levels as measured by education level. In her central case, which controls for the extent to which the economy is open, she obtains estimates that imply that a one percentage point increase in the average corporate tax rate would reduce labor compensation by roughly four times the amount of revenue collected, with little variation across the skill groups. These results also imply a significant amount of overshifting of the burden of the corporate income tax to labor, although considerably less than that reported by Hassett and Mathur.

Because these studies are new and in light of the inherent difficulties of measuring the incidence of corporate tax burdens across countries, the results of these studies must be viewed as quite tentative. Nevertheless, they are generally suggestive of considerable international mobility of capital, and further research examining the robustness of their conclusions is no doubt in the offing.

\section{Saving and Investment Correlations}

Although most of the literature discussed thus far suggests substantial international mobility of capital, an important line of research provides a significant cautionary note. Specifically, this alternative approach to examining the extent of capital mobility, pioneered by Feldstein and Horioka (1980) with subsequent papers by Feldstein (1983), Feldstein and Bacchetta (1991) and Feldstein (1994), focuses on measuring the correlation between domestic saving and domestic investment as an indicator of international capital mobility. Feldstein and Horioka (1980), hereafter $\mathrm{FH}$, note that the fraction of an increase in domestic saving reflected in an increase in domestic investment (termed the "saving retention coefficient" in subsequent work) should be approximately one if economies are largely closed. By comparison, if capital is highly mobile internationally, domestic saving and investment should be nearly uncorrelated, as any increase in domestic saving is distributed across the world economy to maximize after-tax returns and 


\section{Capital Mobility and Capital Tax Competition}

increases in domestic investment are financed from the world supply of capital rather than from domestic saving.

Feldstein and Horioka (1980) examined averages over five years or more of annual domestic saving and investment rates relative to GDP over the period 1960-1974 for a cross-section of 16 OECD countries. They argued that with perfect capital mobility the saving retention coefficient for a given country should roughly equal its share of the world capital stock and, in the aggregate, should be less than 0.10 for their sample of OECD countries. In marked contrast, however, FH estimated that in the basic version of their model the fraction of domestic saving invested domestically was 0.89 for gross saving and investment, an estimate not statistically significantly different from the closed economy value of one. Furthermore, they showed that their empirical results were robust to various extensions of their base model and alternative estimation techniques. Feldstein and Horioka (1980, p. 321) concluded that "the evidence strongly contradicts the hypothesis of perfect world capital mobility and indicates that most of any incremental saving tends to remain in the country in which the saving is done."

Feldstein (1983) extended the analysis to include the mid-1970s, and obtained a somewhat smaller saving retention coefficient of 0.80 , a result that he interpreted as implying that "capital does tend to flow to countries with low savings rates although certainly much less than perfect capital mobility would imply" (Feldstein, 1983, p. 134). He also stressed that his analyses, which estimated savings retention coefficients using observations that were averages over 5-10 years or more, reflected the long run response of international capital movements to differences in domestic savings and investment, and thus were much less likely to suffer from simultaneous equation bias than the alternative methodology (discussed in more detail below) of constructing time series estimates of annual observations for a single country. These results were supplemented by Murphy (1984), who examined two subsets of a group of 17 OECD countries to determine whether relatively small countries, which should approximate small open economies, have lower savings retention coefficients. Indeed, Murphy found this to be the case, as the savings retention coefficient was 0.98 for the seven largest countries in his sample, but 0.59 for the ten smallest countries. 


\section{Capital Mobility and Capital Tax Competition}

Feldstein and Bacchetta (1991) updated the FH study to include data through 1986, observing that during the 1980s international capital flows increased markedly and capital market barriers around the world were lowered or eliminated, suggesting that lower saving retention coefficients might be expected. This conjecture was confirmed in their empirical analysis, extended to include 23 OECD countries over the period 1960-1986, as the estimated saving coefficients declined steadily over the period to a value of roughly 0.61 in 1980-86, considerably lower than the original estimate of 0.89 but still significantly different from zero. They also showed that savings retention coefficients were lower for a subset of their sample consisting of EU countries, falling to a value of 0.36 in 1980-86, and declined more rapidly for this group than for all of the OECD countries in their sample. Feldstein and Bacchetta attributed this result to greater integration of European capital markets, and suggested that this result strengthens the case for the interpretation that relatively higher savings retention coefficients in other less integrated capital markets are attributable to relatively lower levels of informational and institutional links.

A more recent update is provided by Obstfeld and Rogoff (2000), who replicated the FH analysis for a sample of 24 OECD countries over the period 1990-1997, and obtained a similar savings retention coefficient of 0.60 . In addition, they observed that the savings retention coefficient drops to 0.41 when the sample is expanded to 56 countries by adding various smaller and developing countries that are likely to be appropriately characterized as small open economics.

The current state of affairs is thus that estimates using the FH methodology indicate that while savings retention coefficients have declined over time and are relatively small for the highly integrated EU and for the smaller and developing countries that are more likely to be appropriately characterized as small open economies, the estimated coefficients are still considerably higher than the value of approximately zero that $\mathrm{FH}$ argue would be consistent with perfect international capital mobility. Given the other evidence, discussed above, which implies significant international capital mobility - as well as the common perception that capital is highly mobile internationally coupled with widespread use of the assumption of perfectly mobile capital in macroeconomic models (Coakley, Kulasi and Smith, 1998) - this contradictory result has been highly provocative and indeed is commonly termed the "Feldstein-Horioka Puzzle." 


\section{Capital Mobility and Capital Tax Competition}

Indeed, the FH result - as well as their interpretation of its implications - has spawned a vast literature.

This literature has numerous strands. One approach has focused on econometric issues raised by the estimation methods used in the FH paper and its progeny, including their assumption (discussed explicitly in the original FH paper) that a country's saving rate is determined exogenously by structural factors such as demographics, population growth, income, tastes and the nature of social security retirement programs. Coakley, Kulasi and Smith (1998, p. 170) summarize the results of this literature as of the late 1990s as indicating that the "result of a high saving-investment association has remained remarkably robust in OECD cross-sections." More recently, however, Coakley, Fuertes and Spagnolo (2004) argue that estimated savingsinvestment correlations are reduced significantly when more appropriate econometric methodologies are applied. Specifically, they analyze panel data for a sample of 12 OECD countries over the period 1980-2000, modifying the FH approach to correct for country heterogeneity and cross-section dependence in saving and investment rates. They show that in the absence of such corrections, their estimate of the savings retention coefficient is 0.676 , but, once they correct for country heterogeneity and cross section dependence, the saving retention coefficient is virtually zero (0.062). They conclude that, "On the basis of these findings, we tentatively conjecture that that the FH puzzle may well be history" (Coakley, Fuertes and Spagnolo, 2004, p. 587). Nevertheless, the issue is clearly still quite controversial (Evans, Kim and $\mathrm{Oh}, 2008)$.

A second approach, characteristic of the macroeconomics literature on this issue, has focused on analyzing time series regressions of saving and investment correlations in particular countries, rather than the cross-sectional analyses of countries conducted by Feldstein and his co-authors. These time series estimates of the savings retention coefficient vary greatly-e.g., from 0.0630.929 in Tesar (1993), and from 0.025-1.182 in Coakley, Kulasi and Smith (1994). However, the latter set of authors show that the averages of these long run time series estimates are very close to the estimates of the savings retention coefficients obtained in FH-type cross-section studies. More recently, Evans, Kim and Oh (2008) also find a large range of savings retention 


\section{Capital Mobility and Capital Tax Competition}

coefficients (e.g., they find that capital mobility is very high for Canada but quite low for the U.S.) as well as considerable variation in savings retention coefficients over time.

Thus, there is a general consensus that relatively high saving retention coefficients - especially among OECD countries and to a lesser extent among smaller countries, including developing and emerging economies, are an empirical regularity that must be explained. Numerous competing explanations have been proffered, and have been highly controversial, partly because, as stressed by Feldstein and his co-authors, the implications of imperfect international capital mobility are so dramatic. For example, Feldstein and Horioka (1980, p. 328) argue that their results imply that "it is appropriate, at least as an approximation, to study income distribution in general and tax incidence in particular with models that ignore international capital mobility." In particular, Feldstein (1994) notes that the FH results call into serious question the relevance of the most important results of open economy models with internationally mobile capital.

At the same time, Feldstein has stressed that his results should not be "overinterpreted" and agrees that there is considerable evidence of some capital mobility. Instead, he argues that, "The conflict between the evidence that there is global capital mobility and the evidence that there is a global capital market segmentation is more apparent than real. ... Evidence that capital can move and that some capital does move is not the same as evidence the capital is allocated globally without regard to national boundaries" (Feldstein, 1994, p. 11). Thus, he maintains his earlier position that "It is reasonable to interpret the FH findings as evidence that there are substantial imperfections in the international capital market and that a very large share of domestic savings tends to remain in the home country" (Feldstein, 1983, p. 131).

In particular, Feldstein and Bacchetta (1991) and Feldstein (1994) stress that high savings coefficients are not necessarily inconsistent with the capital mobility implied by certain forms of interest rate equalization. Following Frankel (1986), Feldstein and Bacchetta note that perfect capital mobility implies the existence of covered interest parity, that is, equalization of interest rates adjusted for both expected changes in exchange rates and an exchange rate risk premium. They note that the empirical evidence, summarized in Frankel (1992), is generally consistent with covered interest parity. However, Frankel (as well as Feldstein and Bacchetta) stress that the 
existence of covered interest parity does not imply equalization of real interest rates. Indeed, Frankel shows that many groups of countries that are characterized by rough covered interest parity nevertheless also simultaneously exhibit substantial real interest differentials, driven primarily by a currency premium that reflects both expected changes in exchange rates and an exchange rate risk premium.

This distinction is critical, as domestic savings and investment respond to real interest rates and the empirical evidence indicates that real interest rate differentials are not arbitraged away; that is, new increments of saving are not necessarily dispersed across the global economy in search of the highest real rates of return. Indeed, Frankel (1992, p. 200-01) concludes that "there is no reason to expect saving-investment correlations to be zero ... [as] even with the equalization of covered interest rates, large differentials in real interest rates remain." For example, increases in domestic savings could depress the domestic real interest rate, lowering the cost of capital and inducing additional domestic investment, thus generating simultaneous increases in domestic saving and investment and creating real interest differentials without necessarily violating covered interest parity.

Feldstein and Bacchetta agree with this interpretation, arguing that real interest rate differentials are likely to persist, both because purchasing power parity does not appear to obtain even in the long run and certainly not for extended periods of time, and due to a premium for exchange rate risk, which may also be augmented by a premium for the risk of policy changes, including the tax treatment of capital income and, at least in some cases, the possibility of expropriation. As a result, an equiproportionate increase in domestic saving and investment in a country that causes a decline in the domestic real interest rate need not violate the covered interest parity that is consistent with perfect capital mobility. That is, "there is no presumption that real long-term yields would be equalized even if all investors were completely free to invest wherever in the world they want" (Feldstein and Bacchetta, 1991, p. 203).

Frankel argues that this effect is important enough to resolve the FH puzzle, an interpretation with which Feldstein and Bacchetta are sympathetic. However, neither provides evidence linking high saving investment correlations with real interest rate differentials of the appropriate sign. 
Moreover, Obstfeld (1995) argues that this resolution of the FH puzzle is incomplete, since persistence in savings-investment correlations implies persistent changes in exchange rates. In addition, one would expect differentials in real interest rates attributable to currency risks to decline over time, given the availability and increasing use of financial derivatives to hedge such risks. Indeed, in his most recent paper on these issues, Feldstein $(1994$, p. 4) notes that "the growth of the derivatives market has made it possible for cross-border investors to hedge longterm as well as short term currency and interest rate risks," but also observes that because such hedging reduces the returns earned by risky cross-border investment, currency risks still function as an important impediment to international capital flows.

More generally, Feldstein (1994, p. 11) attributes relatively high savings-investment correlations to a reluctance by investors and corporate managers to invest abroad, suggesting important limits on capital mobility when he concludes that, "Capital is mobile but its owners generally prefer to keep it at home. ... The evidence on investment-saving correlations and portfolio composition reflects the fact that ignorance, risk aversion and prudence keep capital close to home." In particular, he argues that investors appear to perceive that the additional return and benefits of diversification that might be obtained from additional foreign investment are more than offset by the additional risks of such investment, in the form of the currency risks discussed above, the uncertainties associated with investing in unfamiliar economies where information is difficult and costly to obtain (Gordon and Bovenberg, 1996; Ahearne, Griever and Warnock, 2004), as well as the political risks of policy changes ranging from increased capital income taxation and greater market regulation to capital controls or convertibility restrictions to outright expropriation in the case of developing or emerging economies. In addition, as noted previously, Feldstein (1994) argues that currency risk discussed above is still an important factor, despite the existence of well-developed derivatives markets, as the costs of hedging currency risks significantly diminishes the higher rates of return that might be obtained with a diversified portfolio. 


\section{Capital Mobility and Capital Tax Competition}

In support of this position, he cites the extensive empirical evidence on the existence of significant "home country bias" in investment portfolios (Gordon and Hines, 2002). ${ }^{8}$ Early evidence of home country bias was provided by French and Poterba (1991), who found that in 1989 approximately $94 \%$ of US portfolios were invested in US securities, with similarly large domestic shares for many other countries. Tesar and Werner (1992) estimated that the diversification costs of such home country bias was on the order of 200 basis points. More recently, the ongoing process of globalization has been accompanied by a decline in the extent of home country bias. Nevertheless, recent studies suggest that home country bias is far from eliminated. For example, Sercu and Vanpée (2007) report that in the U.S. the fraction of total equity invested in domestic securities was 82.2 percent in 2005 , and that this share has declined considerably over the past twenty-five years. Nevertheless, the 82.2 percent figure is still more than twice the benchmark figure of 40.5 percent that would reflect a diversified portfolio in which the share of domestic securities equaled the U.S. share of total world market capitalization. Although home country bias is declining around the world, Sercu and Vanpée report still significant home bias for every country in their sample of 42 countries; the degree of home country bias, however, varies considerably, with relatively smaller values reported for more developed economies, especially those in the E.U. ${ }^{9}$

Thus, although risk-averse investors are increasingly willing to take advantage of investment opportunities abroad, the evidence suggests that they are still reluctant to invest in countries with which they are less familiar than their home country, and strongly averse to both currency risks and political risks, including changes in tax and regulatory policies and, in some cases, the prospect of expropriation. ${ }^{10}$ Finally, although barriers to capital flows have been reduced, they have not been eliminated, and Feldstein notes that even in the U.S. some institutional restrictions

\footnotetext{
${ }^{8}$ Note, however, that there are numerous other potential explanations for home bias, including corporate-personal integration schemes that do not provide shareholder credits for foreign taxes (Fuest and Huber, 2004), differences in economic development, capital controls and withholding taxes (Chan, Covrig and Ng, 2005), and personal tax preferences for dividends paid by domestic firms (Desai and Dharmapala, 2007).

${ }^{9}$ Sercu and Vanpée examine five potential explanations for home country bias: (1) the need to hedge risks in the home country, (2) differentially high costs of foreign investments, (3) information asymmetries, (4) differences in corporate governance and transparency, and (5) behavioral biases. They conclude that all of these explanations, including irrational behavior, play a role in explaining the existing level of home country bias.

${ }^{10}$ Feldstein (1994) also notes that imperfections in the international capital markets are offset to some extent when the foreign subsidiaries of U.S. parents borrow abroad to finance foreign direct investment, effectively availing themselves of foreign funds that, given the segmentation of global capital markets, would not have been invested in the U.S.
} 


\section{Capital Mobility and Capital Tax Competition}

on pension funds and insurance companies hamper the free flow of capital to international investments. Thus, he concludes that, because foreign stocks and bonds are very imperfect substitutes for domestic securities, his empirical evidence supporting segmentation of international capital markets is not surprising.

Numerous other observers, however, have argued that alternative explanations, consistent with perfect mobility of capital, provide more plausible rationales for the high savings-investment correlations found in the FH literature. The following discusses four of the most prominent explanations; for more detailed discussions, as well as a discussion of additional alternatives to the FH interpretation, see Obstfeld (1995) and Coakley, Kulasi and Smith (1998).

First, as mentioned previously, numerous observers have noted that, contrary to the explicit assumption of $\mathrm{FH}$, the saving rate in their estimating equation may not be exogenous, as various factors (e.g., productivity or technology shocks, labor force growth, cyclical factors, etc.) may simultaneously affect both national saving and investment and thus generate the FH result. For example, Obstfeld (1986) constructs a model with perfectly mobile capital and a small open economy with immobile labor that experiences an increase in labor productivity. The increase in the size of the effective labor force stimulates additional investment, while at the same time higher incomes, supplemented by an increase in the fraction of the effective labor force that is relatively young and in its high-saving years, generate increases in savings. Obstfeld simulates savings and investment rates in his model and obtains values that would imply regression estimates of the saving retention coefficient that approximate one. Moreover, if the country experiencing the productivity shock is large, or many or all countries experience the same shock, then the resulting increase in saving will reduce the world interest rate and thus increase investment in the countries affected by the shock, as well as in other countries (Baxter and Crucini, 1993). ${ }^{11}$ However, both Summers (1988) and Feldstein and Bacchetta (1991) argue that these explanations, while interesting from a theoretical perspective, are of limited relevance because adding controls for population growth, productivity growth and income distribution to the FH estimating equations has little effect on the savings retention coefficient. Similarly, Kim

\footnotetext{
${ }^{11}$ In addition, Barro, Mankiw and Sala-i-Martin (1995) obtain high savings-investment correlations in a model that incorporates immobile human capital into the production function.
} 
(2001) finds that business cycle shocks can explain only a very small portion of observed savinginvestment correlations, and Attanacio, Picci and Scorcu (2000) find little evidence of relationships between growth and saving and investment.

A second approach to resolving the FH puzzle draws on the persistent heterogeneity across countries in capital-labor ratios that has been observed in many studies. If capital is mobile, it should be allocated to equalize rates of return, taking into account tax treatment in host and home countries. Because such rates of return on long-lived investments are difficult to measure, numerous researchers have focused instead on the question of whether there has been a tendency toward convergence of economy-wide capital-output ratios, as might be expected if production functions were identical and taxes did not distort the world-wide allocation of capital. However, the empirical evidence suggests that capital-output ratios have not even approximately been converging over time (Maddison, 1991; Obstfeld, 1995; Caselli and Feyrer, 2007). Feldstein (1994) argues that this provides additional evidence of the imperfect mobility of capital. However, an alternative explanation is that such persistent differentials in capital-output ratios arise for other reasons, such as differences in capital costs, or because production functions and natural resources differ across countries as do the mixes of production activities, so that countries differ significantly in their capital requirements (Caselli and Feyrer, 2007; Batista and Potin, 2007). In the latter case, savings-investment correlations will be relatively high even with perfect capital mobility if capital-intensive countries also tend to have high savings rates, providing a potential explanation for the FH puzzle. ${ }^{12}$

Third, Summers (1988) argues that another way in which the FH assumption that national savings and investment rates are exogenously determined may be violated is that high savingsinvestment correlations may simply reflect policy responses to large current account deficits. Specifically, he argues that countries have a strong interest in pursuing policies designed to avoid large trade imbalances. ${ }^{13}$ For example, countries may attempt to limit capital inflows to avoid large changes in exchange rates and in the trade balance that will negatively impact the domestic

\footnotetext{
${ }^{12}$ One problem with this interpretation, however, is that countries with high savings and investment rates do not seem to have the high capital shares in income that would typically be associated with high capital intensities (Mankiw, Romer and Weil, 1992).

${ }^{13}$ See also Artis and Bayoumi (1992).
} 


\section{Capital Mobility and Capital Tax Competition}

traded goods sector, or limit capital outflows because social returns to domestic investment may exceed private returns (e.g., due to domestic taxes or the risks of capital expropriation abroad). However, because the balance of payments on current account equals the difference between domestic savings and investment, such policies by definition will tend to bring domestic saving and domestic investment into balance, creating the correlations captured in the $\mathrm{FH}$ analysis. Summers constructs a simple model in which capital is perfectly mobile and countries set their budget deficits to offset imbalances in net saving and thus the trade balance. He shows that the endogenous budget deficit policy response in his model explains roughly three quarters of the observed correlation between savings and investment; in addition, he argues that the remaining correlation could be explained by other policies designed to bring savings and investment into balance. Summers concludes that high investment savings correlations should not be treated as evidence that capital is immobile internationally, and instead reflect the efforts of governments to maintain external trade balance.

Feldstein and Bacchetta (1991) agree that governments are likely to want to restrict the size of trade deficits in response to political pressure from exporters and the producers of domestic substitutes for imported goods. In addition, they note that policies other than budget deficits, including monetary policies and targeted tax incentives, might be utilized to change the level of saving or investment. However, they also note that the empirical results presented by Summers relating budget deficits and net saving imbalances can just as easily be explained as reflecting the traditional crowding out of private investment by government budget deficits, and they argue that empirical evidence which shows that domestic investment responds similarly to either increases in saving or decreases in the government budget deficit support the traditional crowding out hypothesis. Nevertheless, Obstfeld (1995) concludes that the current account targeting hypothesis provides a compelling explanation for the high savings-investment correlations found by $\mathrm{FH}$.

Finally, a huge literature in empirical macroeconomics is highly critical of the conclusion that high savings-investment correlations imply imperfect capital mobility. The central argument, which dates back to Sinn (1992), is that large savings and investment correlations are not indicative of capital immobility but instead reflect a long-run intertemporal budget constraint that 


\section{Capital Mobility and Capital Tax Competition}

precludes countries from running current account deficits or surpluses indefinitely; this intertemporal solvency constraint implies that in the long run domestic saving and investment must be highly correlated. That is, under this view, the high savings retention coefficients obtained in the FH literature, which is designed to capture the long-run relationship between savings and investment, simply reflect the fact that countries must eventually bring their current accounts into balance. However, in the short run capital mobility allows deviations of saving and investment that would not exist if capital were immobile, and it is longer (albeit temporary) deviations from equality of domestic saving and investment that are the best indicator of greater capital mobility - an interpretation that obviously turns the interpretation of the FH results on its head.

Numerous studies have adopted this approach to measuring capital mobility (e.g., Coakley, Kulasi and Smith, 1996; Coakley and Kulasi, 1997; Hoffman, 2004). Most recently, Pelgrin and Schich (2008) analyze a sample of 20 OECD countries over the period 1960-1999 using a dynamic model that considers the speed of an economy's adjustment to shocks. In contrast to earlier studies, such as Nason and Rogers (2003) and Coakley, Fuertes and Spagnolo (2004), which note that the long run budget constraint applies only in the limit, Pelgrin and Schich (2008) conclude that the relationship across countries between savings and investment is roughly consistent with a binding solvency constraint in a sufficiently long run, especially in recent years. (That is, their empirical results are consistent with the high long run savings-investment coefficients found in the FH literature, although their interpretation is completely different.) At the same time, they find that short run deviations from the long run equilibrium-that is, savings-investment correlations significantly less than one-have become more persistent over time, a result that they interpret as being consistent with increasing capital mobility over time. ${ }^{14}$

Not surprisingly, synthesizing and interpreting all of these conflicting results is exceedingly difficult. In particular, Feldstein's arguments that high savings and investment correlations imply that international capital is relatively immobile certainly suggest that caution is appropriate in

\footnotetext{
${ }^{14}$ In a related article, Obstfeld and Rogoff (2000) construct a model in which they argue that the FH puzzle can be explained by taking into account the costs of trade in goods markets in the presence of large current account deficits. They show that such costs result in dramatic increases in effective real interest rates faced by borrowers when current account deficits become large. The prospect of facing these high interest rates limits current account deficits and thus limits deviations of domestic saving from domestic investment.
} 
simply assuming capital mobility, and that it is inappropriate to model large economies as facing a perfectly elastic supply of capital. Nevertheless, even researchers who have followed in the FH tradition have found savings investment correlations that have declined considerably over time, and that are smaller in more highly integrated economies and in smaller and developing economies, and in one case alternative estimation techniques have resulted in a savings retention coefficient that is virtually zero. In addition, the various alternative explanations of the FH result have some plausibility, and the results and interpretations of the empirical macroeconomics literature raise some troublesome issues with the traditional interpretation of high savingsinvestment correlations, although the practical relevance of the long run solvency constraint is unclear. On balance, a reasonable interpretation may be the now somewhat dated but still highly relevant view of Harberger (1980), who argues that while international capital may not be perfectly mobile, the mobility of capital is relatively high, especially among smaller economies and the developing emerging countries and in the long run, and that with the inexorable march of globalization the level of capital mobility is likely to continue increasing over time-a development that deserves serious consideration in the formulation of tax and other economic policies. $^{15}$

\section{Evidence on Tax Competition}

Assuming that capital is either partially or fully mobile across taxing jurisdictions, a large literature has examined whether countries and indeed subnational governments engage in tax competition designed to attract that capital. This section first examines the predictions of theoretical tax competition models, and then turns to various empirical approaches that have been utilized in an attempt to discern the extent of tax competition.

\section{A. Theoretical Models of Tax Competition}

The early models of tax competition were relatively simple, with an economy consisting of many small identical jurisdictions engaged in Cournot-Nash competition in capital income tax rates to

\footnotetext{
${ }^{15}$ Harberger also argues that the FH result arises primarily because their sample consists primarily of large countries that can easily finance their investment needs from their own saving and can also affect the international return to capital. He provides data that show that relative capital flows are more variable for small countries. Additional support for this view is provided by Murphy (1984) and Mamingi (1994), who find that the saving retention coefficient is much smaller for developing countries than for OECD countries.
} 
attract perfectly mobile capital. In this context, if a tax on immobile local factors is available, then a source-based tax on mobile capital is undesirable - the now-standard "zero tax result" indicative of a "race to the bottom" in capital income tax rates (Zodrow-Mieszkowski, 1983; Gordon, 1986; Razin-Sadka, 1991). The logic underlying this result is that, even purely from the perspective of local residents, a source-based tax on capital income is counterproductive; specifically, such a tax would drive out perfectly mobile capital until the nationally or internationally determined after-tax rate of return to capital was achieved, with the burden of the tax borne entirely by local residents in the form of lower wages and land rents or higher prices for non-tradable goods. As a result, it is preferable simply to tax local residents directly and at least avoid the efficiency costs of the tax, including the effects of capital emigration, lower capital intensities in production, and a tax bias against consumption of capital-intensive goods. ${ }^{16}$ If instead the government is for political or other reasons constrained to utilize a source-based tax on capital income, it is likely to under-provide public services due to concern about driving mobile capital out of the jurisdiction (Zodrow and Mieszkowski, 1986; Wilson, 1986; Bucovetsky and Wilson, 1991; Brueckner, 2000). ${ }^{17}$ In addition, independent of tax competition considerations, these arguments for low levels of capital income taxation may be bolstered by the traditional rationales for consumption-based rather than income-based taxation. ${ }^{18}$ Moreover, several models suggest not only that capital income should not be taxed, but that it should be subsidized. For example, subsidies to capital income may be desirable to attract foreign investment by companies who have relatively poor information on the host countries investment prospects, market conditions, accounting rules, likelihood of expropriation, etc. (Gordon and Bovenberg, 1996), or to offset the effects of imperfect competition in the markets for capital goods (Judd, 1997, 2001).

However, these rather stark predictions have been tempered by numerous models that elaborate in various ways upon the structure of the basic tax competition models. For example, recent extensions have examined the role played by imperfect competition and economic rents,

\footnotetext{
${ }^{16}$ Note that these arguments do not apply for benefit taxes for services provided to mobile capital or taxes designed to compensate for external costs imposed by mobile capital.

${ }^{17}$ On the other hand, tax competition may restrain "Leviathan" tendencies for overconsumption of public services and encourage governments to use desirable user charges and benefit taxes (McLure, 1986; Edwards and Keen, 1996; Huber and Runkel, 2004). See Wilson (1999), Fuest, Huber and Mintz (2003), Wildasin and Wilson (2004) and Zodrow (2003) for discussions of the negative and positive aspects of tax competition.

${ }^{18}$ See Zodrow (2007) for a recent review of these arguments.
} 
especially rents earned by multinational enterprises (MNEs). Although the basic tax competition results obtain if firm-specific economic rents are added (Gordon and Hines, 2002), this is not the case if the economic rents are location-specific, in which case taxation of capital income as a means of capturing some of these rents becomes highly desirable, especially if they accrue to foreign residents. Moreover, the distinction between statutory/average effective tax rates and effective marginal tax rates, which is not an issue in the basic model, becomes very important in this context, as the level of taxation of economic rents is largely determined by the statutory tax rate. Thus, one would also expect tax competition in statutory tax rates as countries attempt to attract highly mobile capital that generates firm-specific economic rents, tempered by the desire to tax location-specific rents, especially if a significant fraction of such rents accrue to foreigners (Devereux and Hubbard, 2003; Huizinga and Neilsen, 1997; Sorensen, 2006). Note that this reasoning suggests that tax competition will be more severe for small economies with little potential for location-specific economic rents. For example, Bucovetsky and Wilson (1991) construct models of asymmetric tax competition where only large countries with market power in capital markets have positive taxes on capital income, and the "new economic geography" models implies that larger "core" countries with agglomeration economies have relatively high tax rates on capital income, which are avoided by relatively smaller and less developed "peripheral" economies (Baldwin and Krugman, 2004).

The difference between statutory and marginal tax rates is also critical when the basic tax competition model is extended to include the potential for income shifting across jurisdictions. Much empirical evidence suggests that multinational enterprises and multistate corporations (in the absence of unitary combination) have considerable latitude in reallocating profits across jurisdictions in response to tax differentials through the use of various financial accounting manipulations, including the use of transfer prices, loans and other intercompany transactions, and judicious allocation of general expenses (Hines, 1999; Altshuler and Grubert, 2002, 2004; Grubert, 1998, 2003; Bartlesman and Beetsma, 2003; Buettner and Wamser, 2007; Desai, Foley and Hines, 2004, 2006) and that such income shifting is increasing over time (Altshuler and Grubert, 2006). The benefits of income shifting are determined primarily by the statutory tax rate, as firms face obvious incentives to shift revenues to jurisdictions with relatively low 


\section{Capital Mobility and Capital Tax Competition}

statutory tax rates and deductions to jurisdictions with relatively high statutory tax rates. The implication again is that tax competition extends to statutory tax rates. ${ }^{19}$

Indeed, several recent studies suggest that if income shifting is sufficiently important, competition in statutory tax rates may be more important than competition in effective marginal tax rates in attracting mobile capital. For example, Haufler and Schjelderup (2000) and Devereux, Lockwood and Redoano (2008) construct tax competition models with income shifting in the form of transfer pricing and show that lowering the statutory tax rate while increasing effective marginal tax rates can be desirable, especially if a local firm is partially owned by foreigners. Similar results were obtained in models in which firms can easily reallocate debt (Fuest and Hemmelgarn, 2005), and in models in which firms are differentially mobile with the more mobile firm generating higher profits (Becker and Fuest, 2005). Thus, because reductions in statutory tax rates simultaneously attract corporations that generate firmspecific rents, reduce the incentives for revenue-decreasing income shifting, and lower the tax burden on marginal investments (as long as this effect is not offset by other measures), tax competition in statutory tax rates may be even more intense than competition in effective marginal tax rates. In addition, consistent with the standard argument that tax competition may lead to under-provision of public services, Gomes and Pouget (2008) provide evidence that such tax competition has led to a significant decline in spending on public infrastructure; they estimate that the decline of roughly 15 percentage points in the statutory corporate income tax rate that has occurred in their sample of $21 \mathrm{OECD}$ countries has led to a reduction in public investment of between 0.6-1.1 percent of GDP.

\footnotetext{
${ }^{19}$ A further implication is that the question of optimal tax design is greatly complicated. For example, many observers have argued that consumption-based taxes are superior to income-based taxes, especially in the context of developing countries (Zodrow and McLure, 1991), partly because they exempt normal returns from tax while taxing economic rents at what is typically a relatively high statutory tax rate. The arguments made above imply, however, that the taxation of rents is far from attractive from the perspective of attracting investments that generate firmspecific rents, and a relatively high statutory tax rate is undesirable because it encourages income shifting. Note that these arguments also imply that the traditional base-broadening, rate-reducing reform, such as the Tax Reform Act of 1986 in the U.S., has important advantages over the alternative of maintaining high statutory tax rates while introducing investment incentives - an approach that is sometimes advocated on the grounds that it maintains high tax rates on existing capital while creating incentives that apply only to new investments (Zodrow and McLure, 1987).
} 


\section{Capital Mobility and Capital Tax Competition}

On the other hand, several factors act to temper tax competition. For example, low taxes on capital income create incentives for income shifting from the personal income tax base, that is, for disguising labor income as relatively lowly taxed capital income (Gordon and Slemrod, 2000). In an international context, host countries that import capital from countries such as the US and the UK that allow foreign tax credits will face an incentive to keep their taxes high to the extent that they will be offset currently by such tax credits; however, as discussed above, this effect is tempered by the facts that such credits are deferred until the funds are repatriated to the parent, many multinationals have excess foreign tax credits, some foreign tax credit countries allow tax sparing, and the use of tax avoidance techniques by some US multinationals to eliminate home country tax liability. Also, if public goods generate significant positive spillover benefits across jurisdictions, the incentive for a government to lower its capital income taxes to attract mobile capital declines to the extent that such a capital reallocation results in lower public services being produced in other jurisdictions and thus lower spillover benefits. Indeed, if local goods are pure public goods and all jurisdictions use capital income taxes, there is no incentive for underprovision of public services (Bjorvatn and Schjelderup, 2002). In addition, numerous policy initiatives have attempted to place constraints on the extent of international tax competition, including the OECD's Initiative on Harmful Tax Competition, the European Commission's Code of Conduct (McLure, 2006), and ongoing discussions about EU corporate income tax harmonization, and several decisions by the European Court of Justice have also had the effect of tempering tax competition within the EU.

Finally, the implications for tax competition of corporate tax avoidance are complex. As noted above, the potential for income shifting creates another dimension of tax competition, especially in statutory tax rates. However, the existence of the potential to avoid the negative effects of higher tax rates suggests that their deleterious effects on investment may be significantly smaller than suggested by the standard tax competition literature (Hong and Smart, 2007). For example, Altshuler and Grubert (2006) argue that tax competition is increasingly taking the form of allowing tax avoidance by multinational enterprises. In particular, they stress that the "check the box" rules in the US greatly facilitated tax avoidance by US multinationals by allowing the creation of hybrid entities that allow the shifting of interest and other forms of income to tax havens without triggering current taxation under the US controlled foreign corporation rules. 


\section{Capital Mobility and Capital Tax Competition}

To sum up, the basic tax competition model as well as several of its extensions suggest that if capital is mobile tax rates on capital income should be relatively low and indeed in some cases should be zero or even negative. Moreover, tax competition extends to statutory rates, especially to the extent such rents are firm specific and firms have the potential to shift income. However, the rather stark results obtained with these models are tempered by a variety of additional considerations, including the desire to tax location specific economic rents, especially if such rents are earned by foreigners. Thus, the extent of tax competition is ultimately an empirical issue. Various strands of the empirical evidence on this question are examined in the following sections.

\section{B. Corporate Tax Rates}

It is clear that statutory corporate tax rates have declined significantly in recent years. For example, Devereux, Griffith and Klemm (2002) note that average statutory corporate income tax rates in the EU and U.S. fell dramatically from $48 \%$ in 1982 to $35 \%$ in 2001 . Similarly, Devereux (2007) shows that the average statutory tax rate in the OECD was roughly 40 percent over the period from 1965 to the early 1990s, but dropped from 41 percent in 1988 to 33 percent in 1993, and was roughly constant at that level through 2004 (when it was 32 percent). At the same time, however, these rate reductions have often been accompanied by base-broadening efforts, so that overall corporate tax revenues as well as average and especially marginal effective tax rates have declined considerably less (Devereux, Griffith and Klemm, 2002; Gorter and de Mooij, 2001; Becker and Fuest, 2005); indeed, corporate tax revenues as a share of total revenues have risen over the past two decades in the U.S. (Auerbach, 2006). Similarly, corporate tax revenues as a fraction of GDP in the OECD have been roughly constant over the past 40 years, and indeed have increased in recent years (Devereux, 2007). ${ }^{20}$ This evidence is suggestive of tax competition in statutory rates, but also implies that tax competition has not yet had as significant an impact in these countries on the effective tax rates that were the focus of the earlier theoretical tax competition models.

\footnotetext{
${ }^{20}$ See Devereux (2007) for a discussion of various additional possible explanations for the relative stability of corporate revenues in light of reductions in statutory rates, including increased inward profit shifting as statutory rates decline, increased shifting of income to the corporate base from the individual base (with large effects found by Gordon and Slemrod (2000) and de Mooij and Nicodeme (2008)), increased relative firm profitability, and increased investment in response to tax reductions. In addition, Auerbach (2006) argues that corporate tax revenues have increased due to an increasing dispersion of corporate profitability, coupled with the fact that profits are taxed while losses are not fully deductible so that the average tax rate on positive income net of losses has increased.
} 


\section{Capital Mobility and Capital Tax Competition}

More generally, although the data are now somewhat dated, Grubert (2001) examines a sample of 60 countries and shows that average effective tax rates, defined as foreign taxes paid relative to net income as reported by US multinationals, fell by almost ten percentage points between 1984-1992, with statutory rates falling by a somewhat smaller amount (and rates in the EU falling by less than this average). This result is more consistent with the existence of tax competition in effective tax rates, as is Grubert's finding that average effective tax rates fell much more in the small, open and relatively poor countries that are more susceptible to the effects of tax competition. Altshuler and Grubert (2006) find that the rate of decline in average effective tax rates continued but moderated over the 1992-2000 period, and that although the declines were more pronounced in smaller countries through 1997, this result vanishes for 19982000. (As will be discussed below, they attribute this result to the increased importance of tax planning and tax avoidance activities.) Similarly, Slemrod (2004) finds that statutory tax rates are negatively associated with measures of openness (although he does not find evidence of such a link for revenues as a fraction of GDP), Winner (2005) finds that decreasing capital tax burdens and increasing labor tax burdens over time are especially pronounced for smaller countries, and Bretschger and Hettich (2002) obtain similar results for statutory corporate income tax rates.

Garretson and Peeters (2006) examine the impact of increasing capital mobility (measured as either increases in FDI flows relative to gross capital formation or using an index of the extent of the legal restriction placed on international capital mobility) on corporate tax rates for a sample of 19 OECD countries. They base their model on the theory of tax competition with agglomeration economies noted above, which posits that tax competition should be less intense among "core countries" that are characterized by significant economies of agglomeration, relative to smaller less developed "peripheral" countries (Baldwin and Krugman, 2004). They find that increased capital mobility does lead to tax competition in the form of lower corporate tax rates, but that this effect is considerably less pronounced for countries with significant agglomeration economies (estimated using several measures of market potential); they conclude (Garretson and Peeters, 2006, p. 1) that, "If there is a race to the bottom, it seems that it is more real for some countries than others." 


\section{Capital Mobility and Capital Tax Competition}

Similarly, Keen and Simone (2004) argue that tax competition has been more pronounced in developing countries, where competition has not been limited to statutory tax rates, but also to average and marginal effective tax rates as well as revenues, primarily due to generous tax holidays and tax incentives designed to attract foreign direct investment. For example, in a sample of developing countries using data from the early 1990s to the early 2000s, average statutory rates declined by six percentage points or $16 \%$, and corporate tax revenues relative to GDP declined by $20 \%$. This result is confirmed by Huizinga, Laeven and Nicodéme (2006) who find that corporate tax revenues relative to GDP decline with size (measured as GDP). However, this result has been questioned by Hines (2007) who examines a longer time period and a different sample of non-OECD countries and finds the corporate tax revenues relative to GDP are roughly constant over the period 1972-2004; even in this case, however, corporate tax revenues relative to GDP decline if one assumes that tax competition was not an important force until the early 1980s. Hines also finds that tax competition has significantly reduced foreign taxes on U.S. multinationals, as their average effective foreign tax rates fell from $43 \%$ in 1982 to $26 \%$ in 1999 .

\section{Reaction Functions}

Another strand of the empirical literature tests for tax competition by looking for evidence of strategic interactions among governments in setting tax rates on capital, as predicted in models of tax competition in which governments take into account the tax policies of neighboring jurisdictions (rather than assuming them to be fixed). Brueckner (2003) surveys the literature that examines this issue in the subnational context, including important contributions by Heyndels and Vuchelen (1998), Brett and Pinkse (2000), Buettner (2001), Hayashi and Boadway (2001) and Brueckner and Saavedra (2001). He notes that the slope of a local government's tax reaction function is theoretically ambiguous in sign. For example, if neighboring jurisdictions lower their tax rates, the standard tax competition argument implies that the local government should react by lowering its own tax rate (a positively sloped reaction function); however, the capital outflow induced by the rate reduction of other jurisdictions implies a reduction in revenues and, if local tastes for public services are sufficiently strong, the local tax rate can increase. Nevertheless, Brueckner (2003) notes that in virtually all of the empirical studies he analyzes, the estimated tax 


\section{Capital Mobility and Capital Tax Competition}

reaction function confirms strategic interaction and is upward sloping, indicating that the traditional tax competition factors dominates. ${ }^{21} 22$

Devereux, Lockwood and Redoano (2008) utilize a similar approach in an international context. Following Devereux and Griffith (1998, 2003), they construct a model in which multinationals choose their investment locations in response to differences in statutory tax rates and choose their level of investment, given location, in response to the marginal effective tax rate. In addition, firms are assumed to be able to use transfer pricing, limited by the threat of audit, to shift profits across jurisdictions. Devereux, Lockwood and Redoano analyze multinational investment decisions in a sample of 21 OECD countries over the period 1982-1999. They find strong evidence of international tax competition over statutory corporate tax rates; specifically, they estimate that a one percentage point reduction in the weighted average statutory tax rate in other countries results in a 0.7 percentage point reduction in the home country tax rate. They also find evidence of competition in marginal effective tax rates, but the magnitudes of the effects are much smaller. ${ }^{23}$ Finally, they note that their estimated government tax reaction functions suggest that equilibrium statutory tax rates should have fallen substantially over the time period considered, consistent with the data described above.

Heinemann, Overesch and Rincke (2008) also provide a recent test for the existence of tax competition. They examine a series of discrete tax reform events involving reductions in statutory tax rates in a sample of 32 European countries to test for interactions among neighboring countries. They estimate that a country reduces its own statutory tax rate by 1.5-3.2 percentage points in response to a reduction in statutory tax rates of one percentage point in

\footnotetext{
${ }^{21}$ The results of these studies, however, cannot identify whether the observed reaction functions reflect tax competition, or alternative explanations such as "yardstick competition" (under which voters evaluate their political representatives relative to those in neighboring jurisdictions).

${ }^{22}$ Note that tax competition among the states in the US, where the allocation of corporate profits across states is determined by formula apportionment with formulas that vary across states, can also take the form of changing a state's formula to increase the weight on sales while reducing the weights on payroll and property, or facilitating tax avoidance in the form of income shifting across states by allowing firms to use separate rather than combined accounting (Edmiston, 2002; Mazerov 2005, 2009). Mintz and Smart (2004) discuss similar issues in the Canadian context.

${ }^{23}$ Devereux, Lockwood and Redoano also argue that the fact that the strategic tax interactions between countries they observe occur only between relatively open economies implies that they cannot be explained by two alternative theories - "yardstick competition" and common intellectual trends, such as a move toward broader tax bases and lower rates.
} 
neighboring countries. Similarly, Altshuler and Goodspeed (2002) estimate that the EU has a positive tax reaction function to tax changes in the US (which they model as a Stackelberg leader) and the tax competition between the EU and US has become increasingly intense, and Besley, Griffith and Klemm (2001) show that corporate income tax rates are positively related to tax rates in other countries, especially within the EU, but such a strategic relationship does not hold for other taxes. All of these studies suggest that international tax competition is an important ongoing phenomenon.

\section{Competition in Allowing Tax Avoidance}

As discussed above, the potential for tax avoidance and income shifting in general provides another explanation for why tax competition in statutory corporate income tax rates might be observed, as lower statutory rates reduce incentives for multinational enterprises (MNEs) to shift revenues out of, and deductions into, a country. However, possibilities for tax avoidance by MNEs also may temper tax competition. Specifically, tax avoidance opportunities may imply that the negative impact of relatively high statutory and effective tax rates on foreign direct investment may be muted if MNEs are easily able to mitigate their effects on the cost of capital with tax planning.

This creates an interesting dilemma for tax policy makers. On the one hand, governments in the industrialized world have for many years engaged in a wide variety of efforts to protect tax revenues by limiting opportunities for tax avoidance and tax evasion by domestic- and foreignbased multinationals; these include extensive transfer pricing rules, controlled foreign corporation limits on earning passive income abroad, thin capitalization and earnings stripping rules, limits on interest deductibility, withholding taxes, etc., as well as treaties designed to limit opportunities for avoidance and evasion. Moreover, the OECD is currently engaged in several long-standing efforts to coordinate policies to limit tax what it deems to be harmful tax competition (European Commission, 1997; Organisation for Economic Cooperation and Development, 1998, 2000).

On the other hand, the availability of strategies for tax planning that are available only to MNEs suggests an interesting "optimal capital income tax" strategy that might be pursued by countries 


\section{Capital Mobility and Capital Tax Competition}

attempting to attract FDI at minimal revenue cost. Specifically, to the extent that MNEs are more mobile than purely domestic firms (and neglecting the higher administrative and compliance costs of differential taxation), optimal tax theory suggests that the former should be taxed at relatively lower rates - indeed, as described above, at a zero rate if they are perfectly mobile (Gugl and Zodrow, 2006). Several studies have examined the revenue effects of preferential tax regimes for mobile capital, reaching different conclusions depending on assumptions regarding the relative mobility of the different tax bases (Janeba and Peters, 1999; Keen, 2001; Janeba and Smart, 2003). In practice, political considerations generally preclude the taxation of foreign firms at rates that are explicitly lower than those applied to domestic firms. However, the same result can be achieved if host countries allow MNEs access to tax avoidance devices-e.g., through explicit regulations or lax enforcement - that are legally or effectively not available to domestic firms.

Indeed, Peralta, Wauthy and van Ypersele (2006) and Hong and Smart (2007) conclude that such practices may be desirable as a means of allowing host countries to approach the "zero tax result" for mobile international capital while still applying a high corporate tax rate to relatively immobile domestic capital. In addition, readily accessible possibilities for tax avoidance imply that real foreign direct investment will be less sensitive to tax rate differentials, thus allowing higher corporate tax rates in host countries to be welfare-increasing for their citizens. ${ }^{24} 25$

Altshuler and Grubert (2006) argue that this phenomenon provides an important explanation of the recent behavior of host countries, as tax competition among countries increasingly takes the form of allowing tax avoidance rather than explicit tax rate reductions. Furthermore, they argue that home countries face an incentive to allow or even facilitate tax avoidance by MNEs if they believe that the gains from increased competitiveness of their MNEs outweigh the associated

\footnotetext{
${ }^{24}$ Similarly, Grubert and Mutti (2001) argue that because taxes due on repatriation can be easily avoided (e.g., through arbitrage transactions involving a conduit company in a third country), their distortionary (and revenue) impacts are relatively small. Altshuler and Grubert (2006), however, acknowledge that the six-fold increase in inflows of repatriated funds into the U.S. in response to the recent temporary rate reduction for repatriated funds calls this view into question.

${ }^{25}$ Bucovetsky and Haufler (2008) make similar points in a model in which mobile multinational firms can change their organizational structures. In contrast, Slemrod and Wilson (2006) argue that the impact of facilitating avoidance is negative once one considers the costs of labor income shifting and the costs of enforcement and administration.
} 
revenue losses. As noted above, the prime example of such behavior is the adoption of the "check-the-box" regulations in the U.S. in 1997, which allowed affiliated firms to choose their tax status as a subsidiary, subject to separate taxation, or a branch, taxed on a pass-through basis to the parent firm, and greatly facilitated various tax avoidance schemes.

Altshuler and Grubert provide several examples of tax avoidance activity made easier by the "check-the-box" rules. In general, these strategies involve circumvention of the "controlled foreign corporation" (CFC) rules that require current taxation of income transferred to tax havens. For example, the new rules allow U.S. firms to use tax haven finance subsidiaries, under which the U.S. parent can inject equity funds to an affiliated company in a low-tax haven that in turn loans the funds to another affiliated company in a high-tax country. Under the former regulations, the payment of interest to the company in the tax haven would have been taxable currently under the CFC rules. However, with the new regulations, the company in the high tax host country can be a "hybrid entity"- one that is treated as a corporation by the host country, but as an unincorporated branch of the company in the tax haven by the U.S. - so that transfers between them are intercompany transfers and thus not subject to the CFC rules. As a result, the company in the high tax country gets a deduction for interest at a relatively high rate, but the associated interest income is taxed at a very low rate in the tax haven, with U.S. tax deferred, perhaps indefinitely.

Altshuler and Grubert provide empirical evidence to support their view that international tax competition increasingly takes the form of allowing tax avoidance, examining various phenomena before and after the 1997 tax change. First, they examine changes in average effective tax rates, which continued to decline over the period 1992-2002, although at a slower rate than the decline documented in the studies cited above. They conclude that after 1998 tax avoidance behavior was much more important in explaining these declines in host country effective tax rates than the declines in statutory tax rates that occurred over the same period, as the correlation between effective and statutory tax rates declined significantly. Second, the extent to which the reported profitability of subsidiaries in low-tax countries exceeded that in high-tax countries grew considerably after 1997, suggesting profit shifting to low-tax jurisdictions. Third, Altshuler and Grubert show that intercompany tax payments and holding company income grew 


\section{Capital Mobility and Capital Tax Competition}

considerably after 1997, as would occur if the various strategies described above were used to shift income to lower-tax countries. They estimate that in 2002 U.S. multinationals saved 15 percent of their total foreign tax burden by using these techniques.

\section{Conclusion}

This paper has examined the literatures on two questions that are essential to any discussion of mobility and taxation - the extent to which capital is mobile internationally and the extent to which the mobility of capital has resulted in interjurisdictional capital tax competition. There is general agreement that capital is mobile and has become increasingly mobile over time, supported by evidence on the responsiveness of the allocation of investment to tax factors, recent empirical estimates of the incidence of the corporate income tax, and gradual reductions in cross country estimates of savings retention coefficients. There is, however, far less agreement as to whether capital is sufficiently mobile that it is reasonable to assume perfect international capital mobility, and especially with respect to whether empirically observed high savings retention coefficients imply the existence of significant impediments to capital mobility, should be interpreted as reflecting other factors, or instead provide little information on the extent of capital mobility. A potentially interesting direction for future research would be dynamic models that explicitly and simultaneously consider differences in life-cycle savings behavior across countries, differences in country size and the degree of openness of the economy, and differences in the extent to which the intertemporal budget constraint is binding across countries, in an attempt to separate and identify the relative importance of each of these factors in explaining the persistence of relatively high savings retention coefficients. Similarly, additional empirical work testing a comprehensive measure of capital mobility defined in terms of equalization of rates of return adjusted for currency and political risk and information asymmetries would appear to be very useful.

The theoretical modeling of tax competition has progressed significantly since the basic models were developed some thirty years ago, encompassing a wide variety of important extensions including especially the modeling of the roles of both location-specific and firm-specific economic rents, tax avoidance, and competition in statutory tax rates. A promising avenue for 
future research is the development of models, such as those constructed by Parry (2003) and Sorensen $(2000,2001)$, that consider explicitly the relative magnitudes of the various effects of tax competition, including beneficial ones, which have been identified but generally treated in isolation in the literature. The bulk of the empirical literature, especially evidence on the evolution of tax rates and the estimation of tax reaction functions, suggests that both subnational and international tax competition is an important phenomenon, and that such tax competition is increasing over time. The most critical question is the nature of any future tax competition, given that the standard base-broadening measures in many countries presumably have been nearly exhausted in recent years, and that the traditional role of the corporate income tax as a "backstop" to the personal income tax is compromised if corporate rates fall significantly below personal rates. ${ }^{26}$ A key question is thus whether future tax competition will take the form of aggressive competition in marginal effective tax rates similar to that already observed for statutory rates, or alternative approaches such as the enactment of provisions that facilitate tax avoidance or lax tax administration that encourages tax evasion — or if tax competition will wane as its costs increase.

\footnotetext{
${ }^{26}$ Slemrod (2004) shows that countries with high personal tax rates typically also have high corporate tax rates, consistent with the "backstop" justification for the corporate income tax.
} 


\section{Capital Mobility and Capital Tax Competition}

\section{REFERENCES}

Ahearne, Alan G., William L. Griever and Frank E. Warnock, 2004. "Information Costs and Home Bias: An Analysis of U.S. Holdings of Foreign Equities." Journal of International Economics 62 (2): 313-336.

Altshuler, Rosanne and Timothy Goodspeed, 2002. "Follow the Leader? Evidence on European and U.S. Tax Competition," Rutgers University Economics Department Working Paper No. 200226.

Altshuler, Rosanne and Harry Grubert, 2002. "Repatriation Taxes, Repatriation Strategies, and Multinational Financial Policy.” Journal of Public Economics 87: 73-107.

Altshuler, Rosanne and Harry Grubert, 2004. "Taxpayer Responses to Competitive Tax Policies and Tax Policy Responses to Competitive Taxpayers: Recent Evidence.” Tax Notes International (June 28) 34 (13): 1349-1362.

Altshuler, Rosanne and Harry Grubert, 2006. "Governments and Multinational Corporations in the Race to the Bottom.” Tax Notes (February 6) 110: 459-474.

Altshuler, Rosanne, Harry Grubert and T. Scott Newlon, 2001. "Has U.S. Investment Abroad Become More Sensitive to Tax Rates?" In International Taxation and Multinational Activity, by James R. Hines, Jr. Chicago: University of Chicago Press, pp. 9-32.

Artis, Michael and Tamim Bayoumi, 1992. "Global Capital Market Integration and the Current Account," in Money and Financial Markets, edited by M. P. Taylor. Oxford: Blackwell.

Arulampalam, Wiji, Michael P, Devereux and Giorgia Maffini, 2008. "The Direct Incidence of Corporate Income Tax on Wages," manuscript, University of Warwick.

Attanacio, Orazio P., Lucio Picci, and Antonelloo E. Scorcu, 2000. "Saving, Growth, and Investment: A Macroeconomic Analysis Using a Panel of Countries," Review of Economics and Statistics 82: 182-211.

Auerbach, Alan J., 2006. "Why Have Corporate Tax Revenues Declined? Another Look." National Bureau of Economic Research Working Paper 12463. Cambridge MA: NBER.

Baldwin, Richard and Paul Krugman, 2004. “Agglomeration, Integration and Tax Harmonization.” European Economic Review 48: 1-23.

Barro, Robert J., N. Gregory Mankiw and Xavier Sala-i-Martin, 1995. "Capital Mobility in Neoclassical Models of Growth," American Economic Review 85: 103-115. 
Bartelsman, Eric J. and Roel M. W. J. Beetsma, 2003. "Why Pay More? Corporate Tax Avoidance Through Transfer Pricing in OECD Countries." Journal of Public Economics 87: 2225-52.

Batista, Catia and Jacques Potin, 2007. "International Specialization and the Return to Capital, 1976-2000," manuscript.

Baxter Marianne and Mario J. Crucini, 1993. "Explaining Savings-Investment Correlations," American Economic Review 83: 416-436.

Becker, Johannes and Clemens Fuest, 2005. “Optimal Tax Policy when Firms are Internationally Mobile.” Working Paper No. 1592, CESifo, Munich.

Besley, Timothy, Rachel Griffith and Alexander Klemm, 2001. "Empirical Evidence on Fiscal Interdependence in OECD Countries," Institute for Fiscal Studies Working Paper.

Bjorvatn, Kjetil and Guttorm Schjelderup, 2002. "Tax Competition and International Public Goods," International Tax and Public Finance 8(2): 111-120.

Boskin, Michael J., and William G. Gale, 1987. "New Results on the Effects of Tax Policy on the International Location of Investment," in The Effects of Taxation on Capital Accumulation, edited by Martin S. Feldstein. Chicago: University of Chicago Press, pp. 201219.

Bretschger, Lucas and Frank Hettich, 2002. "Globalization, Capital Mobility and Tax Competition: The Theory and Evidence for OECD Countries," European Journal of Political Economy 18 (4): 695-716.

Brett, C. and J. Pinske, 2000. "The Determinants of Municipal Tax Rates in British Columbia," Canadian Journal of Economics 33: 695-714.

Brueckner, Jan K., 2000. “A Tiebout/Tax Competition Model.” Journal of Public Economics 77, 285-306.

Brueckner, Jan K., 2003. "Strategic Interaction Among Governments: An Overview of Empirical Studies," International Regional Science Review 26 (2): 175-188.

Brueckner, Jan K. and Luc A. Saavedra, 2001. "Do Local Governments Engage in Strategic Tax Competition?" National Tax Journal 54: 203-229.

Bucovetsky, Sam and John D. Wilson, 1991. "Tax Competition with Two Tax Instruments." Regional Science and Urban Economics 21, 333-350. 


\section{Capital Mobility and Capital Tax Competition}

Bucovetsky, Sam and Andreas Haufler, 2008. "Tax Competition when Firms Choose their Organizational Form: Should Tax Loopholes for Multinationals be Closed?" Journal of International Economics 74: 188-201.

Buettner, Theiss, 2001. "Local Business Taxation and Competition for Capital: the Choice of the Tax Rate," Regional Science and Urban Economics 31: 215-245.

Buettner, Theiss and Georg Wamser, 2007. "Intercompany Loans and Profit Shifting-Evidence from Company-Level Data," International Tax and Public Finance.

Caseli, Francesco and James Feyrer, 2007. “The Marginal Product of Capital," Quarterly Journal of Economics 122(2): 535-568.

Chan, Kalok, Vicentiu Covrig, and Lilian Ng, 2009. "What Determines the Domestic Bias and Foreign Bias? Evidence from Mutual Find Equity Allocations Worldwide," Journal of Finance 60: 1495-1534.

Clausing, Kimberly A., 2007. “Corporate Tax Revenues in OECD Countries,” International Tax and Public Finance 14: 115-133.

Coakley, Jerry and Farida Kulasi, 1997. "Cointegration of Long Run Saving and Investment," Economics Letters 54: 1-6.

Coakley, Jerry, Ana-Maria Fuertes and Fabio Spagnolo, 2004. "Is the Feldstein-Horioka Puzzle History? The Manchester School 72 (5): 569-590.

Coakley, Jerry, Farida Kulasi and Ron Smith, 1994. "The Saving Investment Association," Birbeck College Working Paper No. 10/94.

Coakley, Jerry, Farida Kulasi and Ron Smith, 1996. "Current Account Solvency and the Feldstein-Horioka Puzzle," Birbeck College Working Paper Number No. 8/95R.

Coakley, Jerry, Farida Kulasi and Ron Smith, 1998. "The Feldstein-Horioka Puzzle and Capital Mobility: A Review," International Journal of Finance and Economics 3: 169-188.

de Mooij, Ruud A., and Gaëtan Nicodème, 2008. "Corporate Tax Policy and Incorporation in the EU," International Tax and Public Finance 15: 478-498. de Mooij, Ruud A. and Sjef Ederveen, 2003. "Taxation and Foreign Direct Investment: A Synthesis of Empirical Research.” International Tax and Public Finance 11: 673-693. de Mooij, Ruud and Sjef Ederveen, 2005. "Explaining the Variation in Empirical Estimates of Tax Elasticities of Foreign Investment.” Tinbergen Institute Discussion Paper TI 2005-108/3. Rotterdam: Tinbergen Institute. 
Desai, Mihir, C. Fritz Foley and James R. Hines Jr., 2004. "Foreign Direct Investment in a World of Multiple Taxes," Journal of Public Economics 88 (12): 2727-2744.

Desai, Mihir, C. Fritz Foley and James R. Hines Jr., 2006. “The Demand for Tax Havens," Journal of Public Economics 90 (3): 513-531.

Desai, Mihir A. and Dhammika Dharmapala, 2007. "Taxes and Portfolio Choice: Evidence from JGTRRA's Treatment of International Dividends," Working Paper 13281. Cambridge MA: National Bureau of Economic Research.

Devereux, Michael P., 2007. "Developments in the Taxation of Corporate Profit in the OECD since 1965: Rates, Bases and Revenues.” Oxford University Centre for Business Taxation WP 07/04. Oxford: Oxford University Centre for Business Taxation.

Devereux, Michael P. and Rachel Griffith, 1998. "Taxes and the Location of Production: Evidence from a Panel of U.S. Multinationals.” Journal of Public Economics 68: 335-367.

Devereux, Michael P. and Rachel Griffith, 2003. "The Impact of Corporate Taxation on the Location of Capital: A Review.” Economic Analysis and Policy 33: 275-292.Devereux, Michael P., Rachel Griffith and Alexander Klemm, 2002. "Corporate Income Tax Reforms and International Tax Competition.” Economic Policy 35: 451-495.

Devereux, Michael P. and R. Glenn Hubbard, 2003. "Taxing Multinationals.” International Tax and Public Finance 10: 469-487.

Devereux, Michael P., Ben Lockwood and Michela Redoano, 2008. "Do Countries Compete over Corporate Tax Rates? Journal of Public Economics 92 (5-6): 1210-1235.

Edwards, Jeremy and Michael Keen, 1996. “Tax Competition and Leviathan.” European Economic Review 40, 113-134.

Edmiston, Kelly D., 2002. "Strategic Apportionment of the State Corporate Income Tax," National Tax Journal 55: 239-262.

Erkel-Rousse, Helene and Daniel Mirza, 2002. "Import Price Elasticities: Reconsidering the Evidence." Canadian Journal of Economics 35: 282-306.

European Commission. (1997). "Towards Tax Co-Ordination in the European Union: A Package to Tackle Harmful Tax Competition." COM(97) 495 final.

Evans, Paul, Bong-Han Kim and Keun-Yeob Oh, 2008. "Capital Mobility and Savings and Investment: A Time Varying Coefficients Approach," Journal of International Money and Finance 27: 806-815. 


\section{Capital Mobility and Capital Tax Competition}

Feldstein, Martin, 1983. "Domestic Saving and International Capital Movements in the Long Run and the Short Run," European Economic Review 21: 129-151.

Feldstein, Martin, 1994. "Tax Policy and International Capital Flows." National Bureau of Economic Research Working Paper No. 4851 (September).

Feldstein, Martin and Phillipe Bacchetta, 1991. "National Saving and International Investment," in National Saving and Economic Performance, edited by B. Douglas Bernheim and John B. Shoven. Chicago: University Of Chicago Press.

Feldstein, Martin S. and Charles Horioka, 1980. "Domestic Savings and Capital Flows," Economic Journal 90(2): 314-329.

Felix, R. Alison, 2007. "Passing the Burden: Corporate Tax Incidence in Open Economies," manuscript, Federal Reserve Bank of Kansas City.

Frankel, Jeffrey A., 1986. "International Capital Mobility and Crowding Out in the US Economy: Imperfect integration of financial markets For a Good Markets? in How Open Is the US Economy? edited by R. Hafer. Lexington MA: Lexington Books.

Frankel, Jeffrey A., 1992. "Measuring International Capital Mobility: A Review," American Economic Review 82(2): 197-202.

Frankel, Jeffrey A., 1993. "Quantifying International Capital Mobility in the 1980s," in On Exchange Rates, collected papers of Jeffrey A. Frankel. Cambridge MA: Cambridge University Press.

Fuest, Clemens and Bernd Huber, 2004. "Why Do Countries Combine the Exemption System for the Taxation of Foreign Profits with Domestic Double Taxation Relief?" Journal of International Economics 62: 219-231.

French, Kenneth R. and James M. Poterba, 1991. "Investor Diversification and International Equity Markets," American Economic Review 81(1): 222-226.

Fuest, Clemens and Thomas Hemmelgarn, 2005. "Corporate Tax Policy, Foreign Firm Ownership and Thin Capitalization." Regional Science and Urban Economics 35: 508-526.

Fuest, Clemens, Bernd Huber and Jack Mintz, 2003. "Capital Mobility and Tax Competition: A Survey." In Foundations and Trends in Microeconomics 1:1-62.

Garretson, Harry and Jolanda Peeters, 2006. "Capital Mobility, Agglomeration and Corporate Tax Rates: Is the Race to the Bottom for Real?” De Nederlandsche Bank Working Paper No. 113. 
Gentry, William H., 2007. "A Review of the Evidence on the Incidence of the Corporate Income Tax," Office of Tax Analysis Paper No. 101.

Gomes, Pedro and Francois Pouget, 2008. "Corporate Tax Competition and the Decline of Public Investment," European Central Bank Working Paper No. 928.

Gordon, Roger H. and A. Lans Bovenberg, 1996. "Why is Capital so Immobile Internationally? Possible Explanations and Implications for Capital Income Taxation.” American Economic Review 86: 1057-1075.

Gordon, Roger H. and James R. Hines, Jr., 2002. “International Taxation.” In Handbook of Public Economics, Volume 4, edited by Alan J. Auerbach and Martin Feldstein. Amsterdam: North Holland/Elsevier.

Gordon, Roger H. and Jeffrey K. MacKie-Mason, 1995. "Why is There Corporate Taxation in a Small Open Economy? The Role of Transfer Pricing and Income Shifting." In The Effects of Taxation on Multinational Corporations, edited by Martin Feldstein, James R. Hines, Jr. and R. Glenn Hubbard. Chicago: University of Chicago Press.

Gordon, Roger H. and Joel Slemrod, 2000. “Are 'Real' Responses to Taxes Simply Income Shifting Between Corporate and Personal Income Tax Bases?” In Joel Slemrod (ed.), Does Atlas Shrug? The Economic Consequences of Taxing the Rich. New York and Cambridge MA: Russell Sage Foundation and Harvard University Press.

Gordon, Roger H., 1986. "Taxation of Investment and Savings in the World Economy." American Economic Review 76: 1086-1102.

Gorter, Joeri and Ruud de Mooij, 2001. Capital Income Taxation in Europe: Trends and Tradeoffs. The Hague: CPB Netherlands Bureau for Economic Policy Analysis.

Gravelle, Jane G. and Thomas L. Hungerford, 2007. "Corporate Tax Reform: Issues for Congress," Congressional Research Service Report RL34229.

Gravelle, Jane G., and Kent A. Smetters, 2006. "Does the Open Economy Assumption Really Mean that Labor Bears the Burden of a Capital Income Tax? Advances in Economic Analysis and Policy 6: 1-42.

Grubert, Harry, 1998. "Taxes and the Division of Foreign Operating Income among Royalties, Interest, Dividends and Retained Earnings.” Journal of Public Economics 68: 269-290. 
Grubert, Harry, 2001. "Tax Planning by Companies and Tax Competition by Governments: Is There Evidence of Changes in Behavior? In James R. Hines, Jr., International Taxation and Multinational Activity. Chicago: University of Chicago Press, pp. 113-139.

Grubert, Harry, 2003. "Intangible Income, Intercompany Transactions, Income Shifting, and the Choice of Location." National Tax Journal 56: 211-242.

Grubert, Harry and Rosanne Altshuler, 2008. "Corporate Taxes in the World Economy:

Reforming the Taxation of Cross-Border Income." In Fundamental Tax Reform: Issues, Choices and Implications, edited by John W. Diamond and George R. Zodrow. Cambridge MA: MIT Press.

Grubert, Harry and John Mutti, 2000. "The Influence of Taxation on Industrial Location,” National Tax Journal 53(4): 825-839.

Grubert, Harry and John Mutti, 2001. "Taxing International Business Income: Dividend Exemption Versus the Current System.” Washington DC: AEI Press.

Gugl, Elisabeth and George R. Zodrow, 2006. "International Tax Competition and Tax Incentives for Developing Countries." In The Challenges of Tax Reform in a Global Economy, edited by James Alm, Jorge Martinez-Vasquez and Mark Rider. New York: Springer, pp. 167-191.

Harberger, Arnold C., 1980. "Vignettes on the World Capital Market," American Economic Review 70 (2): 331-337.

Harberger, Arnold C., 1995. "The ABCs of Corporate Tax Incidence: Insights into the Openeconomy Case." In Tax Policy and Economic Growth. Washington D.C.: ACCF Center for Policy Research.

Harberger, Arnold C., 2008. "Corporate Tax Incidence: Reflections on What is Known, Unknown, and Unknowable." In Fundamental Tax Reform: Issues, Choices and Implications, edited by John W. Diamond and George R. Zodrow. Cambridge MA: MIT Press.

Hartman, David G., 1984. "Tax Policy and Foreign Direct Investment in the United States." National Tax Journal 37: 475-487.

Hartman, David G., 1985. “Tax Policy and Foreign Direct Investment.” Journal of Public Economics 26: 107-121. 
Hartman, David G., 1986. "On the Optimal Taxation of Income in the Open Economy." National Bureau of Economic Research Working Paper 1550.

Hassett, Kevin A. and Aparna Mathur, 2006. "Taxes on Wages," American Enterprise Institute Working Paper No. 128.

Hassett, Kevin A. and Kathryn Newmark, 2008. "Taxation and Business Behavior: A Review of the Recent Literature.” In Fundamental Tax Reform: Issues, Choices and Implications, edited by John W. Diamond and George R. Zodrow. Cambridge MA: MIT Press.

Haufler, Andreas and Guttorm Schjelderup, 2000. "Corporate Tax Systems and Cross Country Profit Shifting." Oxford Economic Papers 52: 306-325.

Hayashi, Masayoshi and Robin Boadway, 2001. “An Empirical Analysis of Intergovernmental Tax Interaction: The Case of Business Income Taxes in Canada," Canadian Journal of Economics 34: 481-503.

Heinemann, Friedrich, Michael Overesch and Johannes Rincke, 2008. "Rate Cutting Tax Reforms and Corporate Tax Competition in Europe," Center for European Economic Research (ZEW) Discussion Paper No. 08-20.

Hertel, Thomas, David Hummels, Maros Ivanic and Roman Keeney, 2004. "How Confident Can We Be in CGE-Based Assessments of Free Trade Agreements?” Center for Global Trade Analysis Working Paper 26. West Lafayette IN: Purdue University.

Heyndels, Bruno and Jef Vuchelen, 1998. "Tax Mimicking among Belgian Municipalities," National Tax Journal 51: 89-101.

Hines, James R., Jr., 1999. "Lessons From Behavioral Responses to International Taxation.” National Tax Journal, June, 305-322.

Hines, James R., 2007. “Corporate Taxation and International Competition," in Taxing Corporate Income, edited by Alan J. Auerbach, James R. Hines and Joel Slemrod. Cambridge UK: Cambridge University Press, pp. 268-295.

Hines James R., Jr., and Eric M. Rice, 1994. "Fiscal Paradise: Foreign Tax Havens and American Business.” Quarterly Journal of Economics 109: 149-182.

Hoffman, Mathias, 2004. "International Capital Mobility in the Long Run and the Short Run: Can We Still Learn from Saving Investment Data?” Journal of International Money and Finance 23: 113-131. 
Hong, Quing and Michael Smart, 2007. "In Praise of Tax Havens: International Tax Planning and Foreign Direct Investment," CES-ifo Working Paper 1942 (March).

Huber, Bernd and Marco Runkel, 2004. "Tax Competition, Excludable Public Goods and User Charges," CESifo Working Paper Series No. 1172.

Huizinga, Harry and Soren Bo Nielsen, 1997. "Capital Income and Profit Taxation with Foreign Ownership of Firms." Journal of International Economics 42: 149-165.

Huizinga, Harry, Luc Laeven and Gaetan Nicodème, 2006. "Capital Structure and International Debt Shifting.” European Economy Economic Paper No. 263. Brussels: European Commission.

Janeba, Eckhard and W. Peters, 1999. "Tax Evasion, Tax Competition and the Gains from Nondiscrimination: The Case of Interest Taxation in Europe.” Economic Journal 109: 93101.

Janeba, Eckhard and Michael Smart, 2003. "Is Targeted Tax Competition Less Harmful Than Its Remedies?" International Tax and Public Finance 10 : 259-280.

Judd, Kenneth L., 1997. “The Optimal Tax Rate for Capital Income Is Negative.” National Bureau of Economic Research Working Paper 6004. Cambridge MA: NBER.

Judd, Kenneth L., 2001. “The Impact of Tax Reform in Modern Dynamic Economies.” In Transition Costs of Fundamental Tax Reform, edited by Kevin A. Hassett and R. Glenn Hubbard. Washington, DC: AEI Press.

Keen, Michael, 2001. Preferential Regimes Can Make Tax Competition Less Harmful." National Tax Journal 54: 757-762.

Keen, Michael and Alejandro Simone, 2004. "Is Tax Competition Harming Developing Countries More Than Developed? Tax Notes International 34(13) (June 28): 1317-1325. Kim, Sunghyun Henry, 2001. "The Saving-Investment Correlation Puzzle is Still a Puzzle," Journal of International Money and Finance 20: 1017-1034.

King, Mervyn A., and Don Fullerton (eds.), 1984. The Taxation of Income from Capital. University of Chicago Press: Chicago.

Maddison, Angus, 1991. Dynamic Forces in Capitalist Development. Oxford: Oxford University Press.

Mamingi, Nlandu, 1994. "Saving Investment Correlations and Capital Mobility in Developing Countries," World Bank Policy Research Working Paper No. 1211. 
Mankiw, N. Gregory, David Romer and David N. Weil, 1992. "A Contribution to the Imperative Economic Growth,” Quarterly Journal of Economics 107: 407-437.

Mazerov, Michael, 2005. “The 'Single Sales Factor' Formula for State Corporate Taxes A Boon

To Economic Development or a Costly Giveaway?" Center on Budget and Policy Priorities. http://www.cbpp.org/cms/index.cfm?fa=view\&id=1754

Mazerov, Michael, 2009. “A Majority of States Have Now Adopted a Key Corporate Tax Reform-Combined Reporting." Center on Budget and Policy Priorities.

http://www.cbpp.org/4-5-07sfp.pdf.

McDaniel, Christine A. and Edward J. Balistreri, 2002. "A Discussion on Armington Trade Substitution Elasticities.” U.S. International Trade Commission Office of Economics Working Paper.

McLure, Charles E., Jr., 1986. “Tax Competition: Is What's Good for the Private Goose Also Good for the Public Gander?" National Tax Journal 39: 341-348.

McLure, Charles E., Jr., 2006. “Transfer Pricing and Tax Havens: Mending the Revenue Nets of Developing and Transition Countries," in The Challenges of Tax Reform in a Global Economy, edited by James Alm, Jorge Martinez-Vasquez and Mark Rider. New York: Springer.

Mintz, Jack M. and Michael Smart, 2004. "Income Shifting, Investment, and Tax Competition: Theory and Evidence from Provincial Taxation in Canada," Journal of Public Economics 88: 1149-1168.

Murphy, Robert G., 1984. "Capital Mobility in the Relationship between Saving and Investment Rates in OECD Countries," Journal of international Money and Finance 3: 327-342.

Nason, James M. and John H. Rogers, 2003. "The Present Value Model of the Current Account Has Been Rejected: Round up the Usual Suspects," International Finance Discussion Paper 760, Board of Governors of the Federal Reserve System, Washington, DC.

Obstfeld, Maurice, 1986. "Capital Mobility in the World Economy: Theory and Measurement," Carnegie Rochester Conference Series on Public Policy 24: 55-104.

Obstfeld, Maurice, 1995. "International Capital Mobility in the 1990s," in Understanding Interdependence: and the Macro Economics of the Open Economy, edited by Peter B. Kenen. Princeton: Princeton University Press. 


\section{Capital Mobility and Capital Tax Competition}

Obstfeld, Maurice and Kenneth Rogoff, 2000. "The Six Major Puzzles and International

Microeconomics: Is There a Common Cause?" in NBER Macroeconomics Annual 2000, edited by Ben Bernanke and Kenneth Rogoff. Cambridge MA: MIT Press.

Organisation for Economic Cooperation and Development, 1998. Harmful Tax Competition: An Emerging Global Issue, Paris: Organization for Economic Co-operation and Development.

Organisation for Economic Cooperation and Development, 2000. Towards Global Tax Cooperation: Progress in Identifying and Eliminating Harmful Tax Practices. Report to the 2000 Ministerial Council Meeting and Recommendations by the Committee on Fiscal Affairs. Paris: Organization for Economic Co-operation and Development.

Overesch, Michael, 2009. “The Effects of Multinationals' Profit Shifting Activities on Real Investments," National Tax Journal 62: 5-23.

Parry, Ian W. H., 2003. “How Large are the Welfare Losses from Tax Competition?” Journal of Urban Economics 54: 39-60.

Pelgrin, Florian and Sebastian Schich, 2008. "International Capital Mobility: What Do National Saving Investment Dynamics Tell Us?” Journal of International Money and Finance 27: 331-334.

Peralta, Susan, Xavier Wauthy and Tanguy van Ypersele, 2006. "Should Countries Control International Profit Shifting?” Journal of International Economics 68: 24-37.

Randolph, William C., 2006. "International Burdens of the Corporate Income Tax.” CBO Working Paper. Washington DC: Congressional Budget Office.

Razin, Assaf and Efraim Sadka, 1991. "International Tax Competition and Gains from Tax Harmonization." Economics Letters 37: 69-76.

Sercu, Piet and Rosanne Vanpée, 2007. "Home Bias in International Equity Portfolios: A Review," manuscript, Katholieke Universiteit.

Sinn, Stefan, 1992. "Saving Investment Correlations and Capital Mobility: On The Evidence from Annual Data," Economic Journal 102: 1162-1170.

Slemrod, Joel and John D. Wilson, 2006. "Tax Competition with Parasitic Tax Havens," National Bureau of Economic Research Working Paper No. W12225.

Slemrod, Joel, 1990. “Tax Effects on Foreign Direct Investment in the United States: Evidence from a Cross-Country Comparison." In Taxation in the Global Economy, edited by Assaf Razin and Joel Slemrod. Chicago: University of Chicago Press. 


\section{Capital Mobility and Capital Tax Competition}

Slemrod, Joel, 2004. “Are Corporate Tax Rates, or Countries, Converging?” Journal of Public Economics 88: 1169-1186.

Smallwood, Aaron and Stefan C. Norrbin, 2008. “An Encompassing Test of Real Interest Rate Equalization," Review of International Economics 16(1): 114-126.

Sorensen, Peter Birch, 2000. "The Case for International Tax Co-ordination Reconsidered," Economic Policy 15, 431-472.

Sorensen, Peter Birch, 2001. "International Tax Coordination: Regionalism Versus Globalism." CESifo Working Paper Number 483.

Sorensen, Peter Birch, 2006. "Can Capital Income Taxes Survive? And Should They? CES-ifo Working Paper No. 1793.

Summers, Lawrence, 1988. "Tax Policy and Competitiveness," in International Aspects of Fiscal Policy, edited by Jeffrey A. Frankel. Chicago: University of Chicago Press.

Tesar, Linda L., 1993. “Saving, Investment and International Capital Flows,” Journal of International Economics 35: 69-89.

Tesar, Linda L. and Ingrid M. Werner, 1992. Home Bias and the Globalization of Securities Markets," National Bureau of Economic Research Working Paper No. 4218.

Wildasin, David E. and John D. Wilson, 2004. “Capital Tax Competition: Bane or Boon?” Journal of Public Economics 88: 1065-1091.

Wilson, John D., 1986. “A Theory of Interregional Tax Competition.” Journal of Urban Economics 19: 296-315.

Wilson, John D., 1991. “Tax Competition with Interregional Differences in Factor Endowments." Regional Science and Urban Economics 21, 423-452.

Wilson, John D., 1999. “Theories of Tax Competition.” National Tax Journal 52: 269-304.

Winner, Hannes, 2005. "Has Tax Competition Emerged? International Tax and Public Finance 12 (5): 667-687.

Young, K.H., 1988. "The Effects of Taxes and Rates of Return on Foreign Direct Investment in the United States." National Tax Journal 41: 109-121.

Zodrow, George R., 2003. "Tax Competition and Tax Coordination in the European Union." International Tax and Public Finance 10: 651-671.

Zodrow, George R. 2006. "Capital Mobility and Source-Based Taxation of Capital Income in Small Open Economies.” International Tax and Public Finance 13: 269-294. 


\section{Capital Mobility and Capital Tax Competition}

Zodrow, George R. and Charles E. McLure, Jr., 1987. "Treasury I and the Tax Reform Act of 1986: The Economics and Politics of Tax Reform," Journal of Economic Perspectives 1: 37 58.

Zodrow, George R. and Charles E. McLure, Jr., 1991. "Implementing Direct Consumption Taxes in Developing Countries," Tax Law Review 46: 405-487.

Zodrow, George R. and Peter Mieszkowski, 1983. "The Incidence of the Property Tax: The Benefit View versus the New View." In Local Provision of Public Services: The Tiebout Model after Twenty-Five Years, edited by George R. Zodrow. New York: Academic Press.

Zodrow, George R. and Peter Mieszkowski, 1986. "Pigou, Tiebout, Property Taxation, and the Underprovision of Local Public Goods.” Journal of Urban Economics 19: 356-370.

Zodrow, George R., 2007. "Should Capital Income be Subject to Consumption-Based Taxation?” In Taxing Capital Income, edited by Henry Aaron, Leonard Burman and C. Eugene Steuerle. Washington DC: The Urban Institute.

Zodrow, George R., 2008. “Corporate Income Taxation in Canada," Canadian Tax Journal 56: 392-468. 